\title{
脳の機能的結合に関する定性表現を用いた人型 エージェントに対する情動状態記述の試み
}

\section{Qualitative Description Representing Brain Functional Connection for Human Emotional States toward Human-like Agents}

\author{
田和过 可昌早稲田大学大学院人間科学研究科 \\ Tawatsuji Yoshimasa \\ 村松 慶一 $* 0$
Muramatsu Keiichi \\ Graduate School of Human Sciences, Waseda University \\ wats-kkoreverfay@akane.waseda.jp \\ 早稲田大学 人間科学学術院 \\ Faculty of Human Sciences, Waseda University \\ kei-muraeruri.waseda.jp \\ 松居 辰則 \\ (同上) \\ matsui-t@waseda.jp
}

keywords: Uncanny Valley, Human Agent Interaction, Brain Functional Connection, Qualitative Description

\begin{abstract}
Summary
In the research field of Human-agent interaction, the uncanny valley is the crucial issue to realize co-existence of human and artificial agents. It is referred to as the phenomenon that human can feel repulsive against the agents whose appearance is considerably humanlike. There has been just theoretical based but not verifiable model providing an explanation for how it occurs. We hypothesized that when human observes that humanlike agent, s/he perceives it as both human and non-human, and the contradiction between the perceptions causes him or her to elicit negative response against it. We conducted the experiment where the participants were asked to judge whether face of agents or a person was depicted as that of a real person, with their eye tracked and their gaze direction estimated. The results indicated that observers had two-step information processing to the agent. Above all, we proposed a model generating the human negative response against humanlike agents, taking into consideration of the function of the brain regions such as amygdala, prefrontal cortex, hippocampus, and striatum. To verify the model, the transition of the emotional value (namely, positive or negative) was simulated on the basis of a qualitative description for the model. It is suggested that the model be proposed which is verifiable with many findings in the field of neuroscience.
\end{abstract}

\section{1. は じめに}

外的表現を有し知的に振る舞うソフトウェアェージェ ントや物理的身体を有するロボット (以下 , 合わせてェー ジェント) と人間の共生の在り方を考える上で, エージェ ントを介したインタラクションにおける人間の特性を理 解することは重要である.特に, 近年の映像技術や工業 技術の発展に伴うェージェントの人型化において,「不気 味の谷」[森 70] と呼ばれる現象が注目されている .一般 的に，エージェントの外見が工業ロボットのような機械 的なものよりも，手足や顔の表現が与えられ，人間の外 見に近づいたものの方がエージェントに対する親和度は 高いと考えられる.このことから図1(破線)のように，横 軸に人間に対するエージェントの類似度, 縦軸にエージェ ントに対する人間の親和度をとると, 両者の関係は単調 増加の関係が予想される．ところが，一般的には図 1(実 線)のように, 人間に対する類似度が極めて高いある地

$* 0$ 現在は, 埼玉大学大学院理工学研究科に勤務
点において , 急激に親和度が負の方向へと転落すると考 えられている.また, さらに類似度が高くなり, 人間と ほとんど区別がつかなくると, 親和度が正の方向へと 回復し, 完全に人間との類似度が等しくなった時に高い 親和度が得られると考えられている .このような類似度 と親和度の描くグラフの形状から，高い類似度における 急激な親和度の下落を不気味の谷と呼心： [森 70] .

これまで樣々な分野において, 不気味の谷が生起する 要因を理解する試みがなされてきた . 不気味の谷が生起 する要因として目の形態的異常 [Seyama 07]や, 人の顔 のCG 画像におけるテクスチャや目などの顔の部位の配 置 [MacDorman 09] か関わっていることが心理実験を通 して示唆されてきた .これらは, 谷の底にあるエージェ ントがどのような物理的特徵を有しているかを, 各エー ジェントに対する心理的評価をもとに明らかにするとい うアプローチであると言える

しかし, このエージェントに対する不気味さの生起と いう心的状態の変化が, どのような情報処理メカニズム 


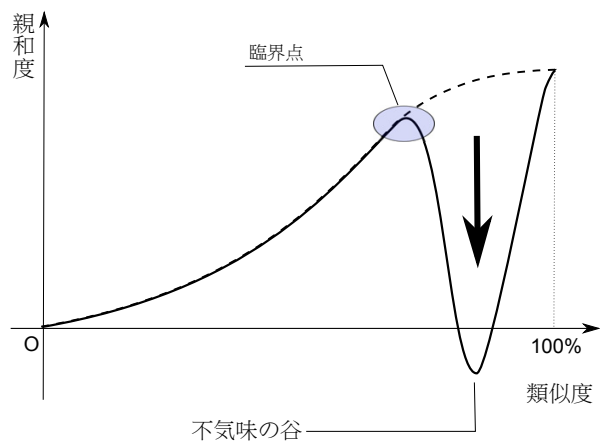

図 1 不気味の谷の概念図 (文献 [森 70] を参考に作成)

によって構成されているか，といった課題に着目した研 究は少ない，一般的に，人間の心的状態の変化の樣子を 記述するためには,心的モデルを構築し, シミュレーショ ンを行うことで光の妥当性を確認するという構成論的ア プローチが有効である . Moore は , 図 1 のグラフの形状 が , 知覚心理学における「知覚のマグネット効果」の説 明モデルを用いると説明できることを示した [Moore 12] . ここでは, 人間に対する類似度が高いェージェントを観 察する際，対象が人間であると知覚する働きと，非人間 であると知覚する働きとの二つの知覚が働き，光れらに よって生じた知覚の歪みが不気味さを生起させると考え られている . 具体的には, 刺激に対して人間であると知 覚 (ターゲット知覚) する確率分布と, 人間でないと知 覚 (バックグラウンド知覚) する確率分布を事前確率分 布として設け，知覚された刺激が人間／非人間のいずれ にカテゴリ化されるかをべイズ推定の枠組みで計算する と, 不気味の谷のグラフの形状が得られるというもので ある

ところが Moore のモデルは, 実験を通して構筑された ものではなく, 既存の理論モデルを不気味の谷のグラフ 形状に対する説明のために適用したものであり，以下の 三点に関して追加検討の余地がある.一点目は, エージェ ントに対する人間のどのような情報処理がモデル化され ているのかに関して明確でないという点である . 二点目 は，上記の情報処理がどのような機能によって実現され ているのかという点である.三点目は，モデルの妥当性 に関する検証可能性が十分に保証されていないという点 である .これら三点を解決する方法として脳機能に着目 することの意義について述べる．

森は, 不気味の谷を本能的な自己防衛反応として位置 付け，死人や異なった種などに対する防衛のために不気 味という感覚が存在すると考えた [森 70] . また，不気味 の谷に見られる否定的反応に関しては, マカクザルでも 生起することか報告されており，自分の属する種に似せ て作成された CG モデルに対して視線を向けようとしな い [Steckenfinger 09] .これらから，不気味の谷における 否定的反応は人間固有のものではなく，種を超えて存在 し, 自己防衛反応に関係があることが示唆される．つま
り，種を超えて共有されている防衛本能システムが否定 的反応を形成していると考えられ，このことから，系統 的に古い脳部位の機能に着目することは否定的反応がい かに形成されるかを理解する上で有用であると考えられ る.Shimada らは人間の知覚情報処理メカニズムのうち 側抑制に着目し，人間に極めて類似したエージェントに 対する人間の知覚情報処理過程をモデル化した [Shimada 07] . この結果 , エージェントから知覚される人間への類 似性は, 極めて類似度の高いェージェントにおいて低く なることが示唆された . また, 神経科学の分野において 提唱されている感情の二重経路の概念を用いて, 不気味 さ生起に関する説明を試みている。

このように, 人間の知覚情報処理メカニズムや神経科 学的知見に基づくモデルが提案されてはいるが，これま で各脳部位の機能を踏まえた不気味さ生起モデルに対し てシミュレーションを通した妥当性の検証は行われてい ない. 乥こで, 本研究では不気味さ生起に関わると考え られる脳部位および脳機能を既往研究から同定し, 乥れ らをもとに不気味さ形成に関わる機能的神経網モデルを 提案する.

まず，Moore のモデルが人間のどのような情報処理を モデル化しているかを実験を通して明確にした上で, 脳 機能という観点からモデルを再構築し, 自然な形で拡張 することを目指す．このモデル構築によって，不気味さ という複雑な感覚がどのような情報処理過程に基づいて 構成されるか，また产の不気味さがどのような神経基盤 によって形成されているかを明確化することが可能であ ると考えられる .

本論文では，まず， Moore のモデルにおける二つの知 覚と光の知覚の歪みの考え方に即して，次のような仮説 を設けた .すなわち,「臨界点右近傍より高い類似度をも つェージェントにおいて，観察者には二つの異なる知覚 過程が働き，光の跙䶣によって不気味の谷が生起する」 という仮説である.第 2 章では，仮説から，対象を人間 として知覚/判断する過程と非人間として知覚/判断す る過程の二つの過程でどのような違いがあるかを，人間 観察時と非人間観察時の被験者の視線の動きを計測する ことで明らかにする．この実験の結果，人間に似たエー ジェントにおいて人間であると知覚する過程と非人間で あると知覚する過程がこの順に存在する可能性が示唆さ れたため，この点を踏まえて仮説を再構築する.第 3 章 では, 第2 章において示唆された二つの異なる知覚過程 がどのようなメカニズムによって生じているかを脳科学 的見地からモデル化する.第 4 章, 第 5 章では, 構築し たモデルを定性的表現によって記述し，人間のエージェ ントに対する情動状態が時系列的にどのように変化する かに関してシミュレーションを行い, 弚の結果に関して 述べる。 


\section{2. 人間／非人間判断時の視線の動きに関する 実験}

人間が人間に酷似したエージェントを観察する際,どの ような知覚過程が伴うのかを実験的に検討する . Minato らは被験者らの視線を計測することで, アンドロイドと 対話中の被験者の視線の動きを，人物と対話中の場合の 視線の動きと比較した [Minato 04] .この結果，他者を観 察する場合と比較して, 被験者はアンドロイドの目に視 線を比較的長く向けることか明らかになった．しかし，こ の実験では予めアンドロイドが人間ではないことが了解 されているため，光も光も被験者の視線の動きが一般的 に他者に対して表出される視線の動き [Yarbus 67] と異な る可能性がある．また，この実験では被験者の視線から 得られた情報 (目鼻口に対する視線停留頻度) をインタ ラクションの時間すべてで圧縮して計算しており，イン タラクション中の被験者が , 各エージェントに対してど のような知覚処理を行っていたかか時系列的に比較され ていない，乥こで本実験では，明らかに人間であると判 断されるェージェントに対する知覚処理と，明らかに人 間ではないと判断されるェージェントに対する知覚処理 においてどのような差が見られるかを, エージェントの 人間/非人間判断中の被験者の視線情報を計測し，時系 列的に分析することで明らかにする．従って，まず本章の 前半で, 5 種類の刺激のうちから人間あるいは非人間と 明らかに判断されるもの, 判断が困難なものの 3 種類の 刺激を分析対象として選定する. 次に本章の後半で, 光

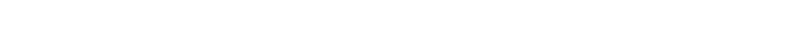
ジェントに対する知覚情報処理のモデルに関して述べる .

\section{$2 \cdot 1$ 実 験 手 順}

本実験では, PCに刺激画像を提示し，兴れが人間か非 人間のいずれであるかを判断する課題を被験者に与えた . 提示された画像を图 2 に示す.光れ, (a) 人形, (b)CG 描写された男性 , (c) 女性の人型アンドロイド, (d)CGで 作成された女性，(e)人間の男性である。これらの顔画像 は，図の左から右に向かうにつれて見かけの人間に対す る類似度が上昇するように主観的に選択した ${ }^{* 1}$. 予め被 験者には各画像を 1 分間提示すること，提示されている 間は画像をよく見るように教示を行った．また，各画像 の提示後は「十」が中央に配置された白い画面へと切り

*1 各画像は下記 URL から取得した . : http: //plaza.rakuten.co.jp/norikodoll/ diary/200902220000/,http://www. giantbomb.com/profile/moeez/blog/ uncharted-2-too-cinematic-for-its-own-good/ 37574/,http://www.uxgroundswell.com/2010/05/ $a-r u n-i n-a t-t h e-u n c a n n y-v a l l e y$ (2012年 5 月 13 日 参 照), http://josiahbancroft.blogspot.jp/ 2010/07/uncanny-valley-is-cayon-part-1. $h t m l(2012$ 年 5 月 13 日参照), http://search. yoshimoto.co.jp/actor_prf/details.html?id= 3120
替わるので, この間に，画像が人間であると思ったなら $\ulcorner\bigcirc 」$ ，人間でないと思ったなら「メ」を，手元に用意し た用紙に記入するよう指示した。解答が終わると視線を $\ulcorner+」$ の央に合わせるよう指示し, 確認か取れたのちに 次の画像の提示を行った . また，一部被験者には実験後 にアンケートの回答を求めた .このアンケートでは, 実 験で提示した各画像に関して, (Q1) 人間/非人間判断 においてどの程度判断に迷ったか (3 段階の評定尺度を 用いて回答；1:迷わなかった，2:どちらでもない，3:迷っ た）,(Q2) 人間/非人間の判断を行うにあたって，画像 のどの部分に着目して画像を観察していたかを，弚れ光 れ実験中の刺激を提示しながら口頭で回答してもらった . 実験課題では，画面に提示される画像を視認できるかを 確認した上で実施した . 被験者の視線は, ナックイメー ジテクノロジー製のEMR-AT VOXER を使用し，利き目 の注視位置を計測することで記録した 。

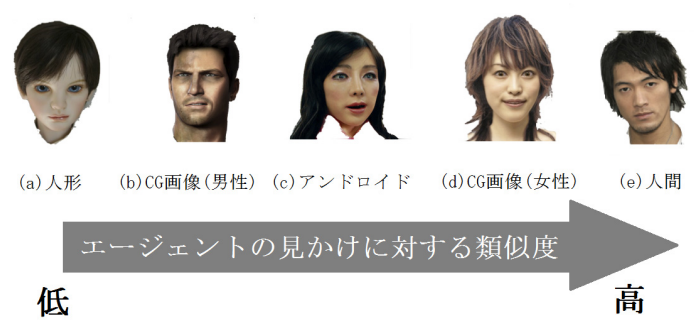

図 2 実験で用いた刺激顔画像

\section{$2 \cdot 2$ 分 析}

一般的に人間は他者を観察する際，目鼻口に対して視 線を多く向けることが知られている[Yarbus 67] . 弚こで， これらを特徵部位として各々に対する視線停留時間を算 出し，画像間で停留時間の長さに差が見られるかを検証 した . 視線停留時間の算出には, 視線データ解析用ソフ トウェア dFactory (ナックイメージテクノロジー製) を 用いた .この分析にあたってはまず，dFactory によって， 画像を提示した画面を $16 \times 16$ の小領域に分割し，各領 域ごとに計測の開始からある時間までの期間における視 線停留時間の合計を算出した．各画像における「左目」 「右目」「鼻」「口」は光れ艺れ瞳の中心 , 鼻頭 , 口の中心 を含む領域と光の周囲を含む 9 領域で定義し, 各特徵点 における視線停留時間は各 9 領域の停留時間の合計で定 めた . 例として図 3 にCG 画像 2 において上記方法で定 義された「左目」「右目」「鼻」「口」の領域を示す．この 定義では特徵部位間において重複が生じる．しかし，視 線計測は誤差を含んでいることか想定されるため, 誤差 を包括することを考慮して，重複を認めた分析を行った． また, 視線停留時間を求める際の時間長を $T$ として計 測開始から 5 秒間 $(T=5), 10$ 秒間 $(T=10), 30$ 秒間 $(T=30)$ の 3 種類を設け, 知覚処理における時系列的変 化の抽出を試みた . 


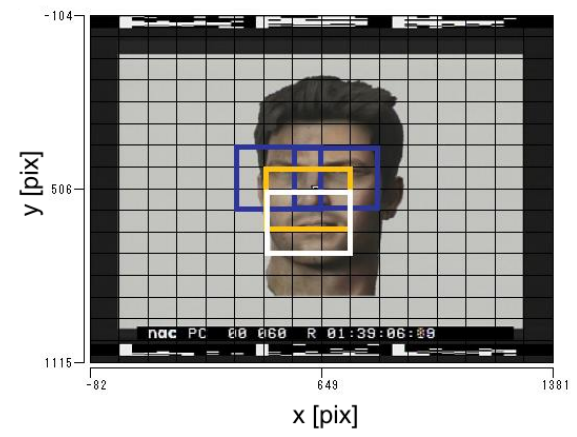

図 3 分析対象となる目鼻口の定義 (各色枠で囲まれた箇所が右 目，左目，鼻，口を表す領域)

\section{$\mathbf{2} \cdot \mathbf{3}$ 結果}

\section{$\S 1$ 各画像に対する人間／非人間判断}

本実験に参加した被験者は, 大学学部学生 21 名 (男

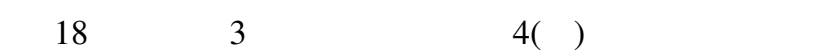
画像に対して「人間である」と判断した人の割合を示す。 具体的には, CG 画像 2(図 2(b)) が 19.1\%，アンドロイド (図 2(c)) が $19.1 \%$, 人形の画像 (図 2(a))) が $28.6 \%, C G$ 画像 1(図 2(d)) が $90.5 \%$, 人間 (図 2(e)) が 100\%，とこ の順に高くなった . 乥こで, 多くの被験者が「人間」と 判断した CG 画像 1 を「人間に対して高い類似度を持つ CG 画像」,すべての被験者が「人間」として判断した人 間画像を「人間」, および多くの被験者が「非人間」と 判断した CG 画像 2 を「人間に対して比較的低い類似度 を持つCG 画像」として，これら三つの画像に対する被 験者のデータを分析した。

\section{$\S 2$ 人間/非人間判断困惑度}

アンケートに回答した 13 名の被験者の, 刺激画像に対 する人間/非人間判断の困惑度は以下の通りであった .人 間画像では, 平均 $1.17(S D=0.39), \mathrm{CG}$ 画像 1 では, 平 均 $1.83(S D=0.72), \mathrm{CG}$ 画像 2では平均 $1.17(S D=$ $0.58)$.また , 困惑度に関して刺激間で差が見られるか $\mathrm{t}$ 検定を行ったところ, CG 画像 1 と CG 画像 $2(t(22)=$ $2.57, p=.020)$, 人間画像と CG 画像 $1(t(16.955)=$ $-2.83, p=.012)$ に有意差力認められた .一方, 人間画像 と CG 画像 2 では有意な差が認められなかった $(t(22)=$ $0.00, p=1.00)$.

\section{$\S 3$ 各特徵部位における視線停留時間}

視線停留時間を分析するにあたっては，CG 画像 1 を 「人間」, CG 画像 2 を非人間」と判断した被験者 15 名 分のデータを対象とした.さらに, 視線データの大部分 の欠損が見られる被験者 7 名分のデータを除外し，残り の 8 名を最終的な分析対象とした . また, 後述するソフ トウェアによる視線停留時間計算において, 被験者 1 名 の 10 秒間の視線停留時間に対して異常な計算結果（計 算対象時間が 10 秒間であるにもかかわらず，17 秒間の 視線停留があると計算された) が確認されたため,さら に 1 名を分析対象から取り除いた。したがって, 7 名が

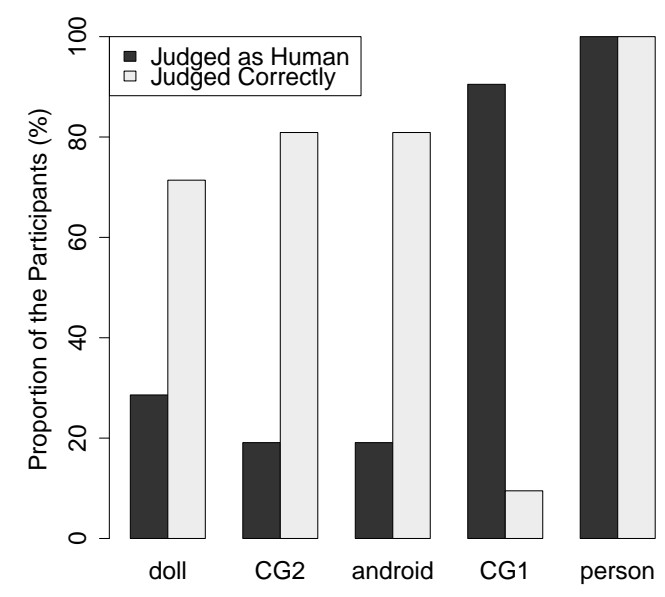

図 4 各画像に対して人間であると判断した人物の割合 (黑) と正答 した人物の割合 (白)

最終的な分析対象である.データ欠損に関しては，視線 計測中に計測器が被験者の視線追跡を外してしまうなど のシステムの問題によるものが試行全体を通して多数確 認されたものを分析から除外した .

图 5 に各時間長における画像ごとの左目 , 右目 , 鼻, 口 に対する視線停留時間の平均の推移を示す. 各時間長 $T$ において,画像間の各特徵部位に対する視線停留時間の平 均に差があるかどうかを $\mathrm{F}$ 検定による等分散性を確かめ たのち，t検定 (等分散が仮定できない場合は，Welchの $\mathrm{t}$ 検定) を施した .このとき, 右目 , 鼻 , 口の一部に有意差 か認められたため, 各時間長に関して述べる . まず開始か ら 5 秒の段階では，右目と鼻に関して有意差および有意 傾向か認㕫られた。右目に関して, CG 画像 1 と CG 画像 2 の間 $(t(12)=3.43, p=.005)$ と, $\mathrm{CG}$ 画像 1 と人間の間 $(t(12)=2.83, p=.015)$ に有意差か認吼れた .一方，鼻 に関して CG 画像 1 と CG 画像 2 の間 $(t(12)=2.00, p=$ $.069)$ と, $\mathrm{CG}$ 画像 1 と人間の間 $(t(12)=2.05, p=.062)$ に光れ有意傾向か認められた．次に開始から 10 秒の 段階では, 右目と鼻，口に関して有意差および有意傾向 が認められた . 右目に関して CG 画像 1 と CG 画像 2 の 間 $(t(8.544)=3.44, p=.008)$ と, $\mathrm{CG}$ 画像 1 と人間の間 $(t(12)=4.29, p=.001)$ に有意差力認吼た ·また ，鼻 に関して CG 画像 1 と人間の間 $(t(12)=3.02, p=.011)$, 口に関して CG 画像 2 と人間の間 $(t(12)=2.43, p=.032)$ に光れ有意差が認められた。最後に開始から 30 秒 の段階においては，右目と鼻に関して有意差および有意 傾向か認められた . 右目に関して, CG 画像 1 と人間の 間に有意差が認められた $(t(12)=2.50, p=.028)$. また， 鼻に関して CG 画像 1 と人間の間に有意傾向か認められ た $(t(12)=2.05, p=.062)$. 

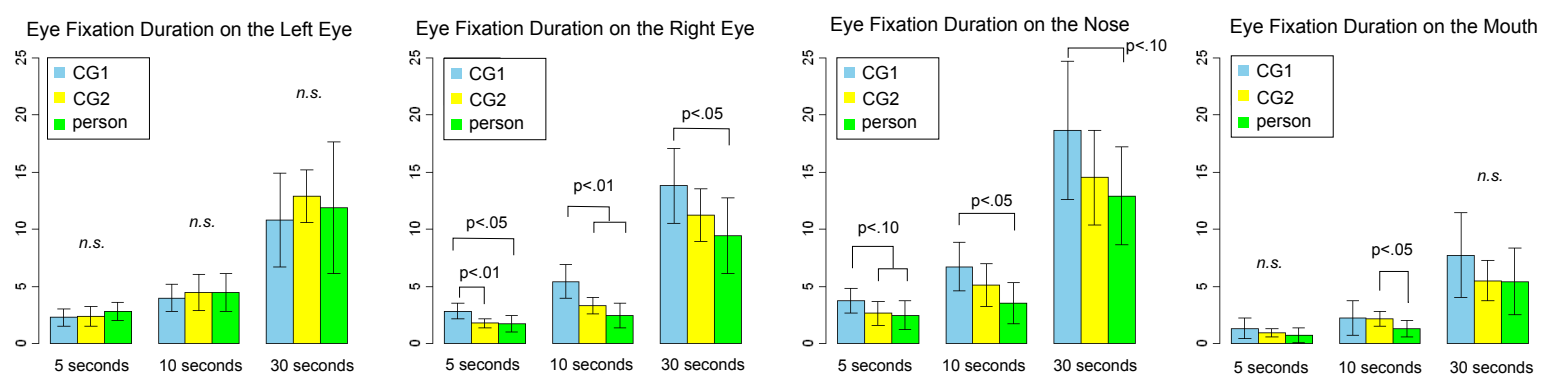

図 5 観測開始から 5 秒, 10 秒, 30 秒間の被験者の左目，右目，鼻，口に対する視線停留時間 (秒) の平均

\section{$2 \cdot 4$ 考察}

分析の対象となった被験者は, $\mathrm{CG}$ 画像 1 および人間 を「人間」, CG 画像 2 を「非人間」であると判断してい る. Cheetham らは, 人間の顔画像から生成した CG 画 像と人間の顔画像をモーフィングによって段階的に調整 し, 人間への類似度を変化させた顔刺激を作成した上で，

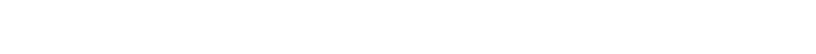
を被験者に課した [Cheetham 13] .この結果, 類似度の 増加に対して人間であると判断する被験者の割合がロジ スティック関係に増加するカテゴリ知覚の樣相が確認さ れた . 本実験においても，このカテゴリ知覚の樣相に近 い形状を有していたことが刺激に対する人間判断率から 推察される.

次に，右目に対する視線停留時間に着目すると，他の 顔特徵部位と比較して刺激間で特徵的な变化が確認され た .具体的には, CG 画像 1 の右目に対する視線停留時 間は, すべての時間長に対して人間の右目に対する視線 停留時間よりも長くなる傾向か認められた . また, CG 画 像 2 の右目に対する視線停留時間は，観測時間が経過す るに従って, 人間の右目に対する視線停留時間と比較し て定性的に長くなることが示唆された .ここから, 間違 いなく人間でないと判断された刺激は, 間違いなく人間 であると判断された刺激に比へてて，右目に対する視線停 留時間が長くなる傾向があることが考えられる . Minato ら [Minato 04] の報告において，人間と対話する場合の 対象の目に対する視線停留頻度は, アンドロイドと対話 する場合よりも短くなることか涽摘されている．30秒の 時間が経過すると人間の目に対する視線停留時間が最も 短くなったことから，本実験での対話のないインタラク ションにおいてもこれが再現されたと考えられる．一方 で, 本実験における 5 秒と比較的短い観察時間では, 人 間でないと判断されたェージェントの目に対しても「人 間」観察時とほぼ同等の視線停留時間であったことから， インタラクション初期の段階においては，正しく人間／ 非人間の判断がつく場合は, 顔知覚処理に関しては違い は見られないと考えられる .

このような右目に対する傾向，すなわち観察者から見 て顔の左側に見られた傾向は, 顔情報処理の観点から考 察される. Thomas らは, 人間が他者の顔を観察する際，
全体的に (観察者から見て) 顔の左側に視線が集まるこ と，特に，悲しい顔を観察する場合は，より顕著に顔の左 側に視線が集まることを実験的に明らかにした [Thomas 14] . また , この悲しい顔における左側優位の視線停留は， 右脳が否定的な情動によって賦活されるという提言と一 致する，と考察している.このことを踏まえると，判断 に困惑させた CG 画像 1 は実験の早い段階で否定的な情 動を被験者に与えていたことが考えられる．また，一方 で，CG 画像 2 は時間が経過するに従い右目に対する視 線停留時間が定性的に長くなったこと，CG 画像 1 の右 目に対する停留時間とほとんど变わらない停留時間が観 測されたことから，観察途中で否定的な情動を被験者に 与えていた可能性が示唆される .

\section{5 人間に似たエージェントに対する二段階の情報処理}

Cheetham らは, 人間のカテゴリ知覚の観点からアバ ター (人間の顔から作成した比較的類似度が低いCG 顔 刺激) 知覚の場合はアバター (非人間カテゴリ) である と反応する潜時が，カテゴリの境界に位置する顔刺激を 知覚する場合に比へて短いことを実験的に明らかにした [Cheetham 13] .これに加え，アバターに対する反応潜時 に比へ，人間ともアバターとも区別のつかないCG 画像 に対する反応潜時に比較的時間がかることから，区別 のつきやすいアバターを知覚・認識する際は比較的粗い情 報処理が行われているのに対し, 刺激の類似度が高くな るにつれ処理時間の要する精緻な情報処理がなされてい るという course-to-fine 仮説を提唱した [Cheetham 13] . この点から考えると人間や CG 画像 2 に関しては, 人間 /非人間であると早期の段階で判断されたと考えられる。 また一方で, 人間であると判断された CG 画像 1 に関し ては，右目に対する視線停留時間が他よりも初期の段階 から長いため, 精緻な情報処理がなされていたと考えら れる。

また人間/非人間判断における困惑度の結果からも， 人間画像と CG 画像 2 の間には差が見られず, 各々の画 像の人間/非人間判断に関しては容易に判断ができたと 考えられる .一方で, 二つの刺激画像の右目に対する視 線停留時間は, 観察時間が経過すると定性的に差が見ら れ始めた .ここから，人間に類似したエージェントに対 
して人間は二段階の情報処理を行うと考えることができ る.すなわち，インタラクション初期の「人間を観察し ているときと同等の処理」と，中期から後期にかけての 「非人間を観察しているとき特有の処理」である.この後 者の処理は，Cheetham らが提案した精緻な情報処理が 必要であるという点と対応すると考えられる．

以上から， Moore のモデルから構築した仮説における 二つの知覚情報処理は，この二段階の情報処理過程にあ たると考えることができる．したがって，不気味の谷を 説明するモデルとして, 新しく次のように考えることが できる．つまり，人間に似たエージェントを観察した際 に, 人間の知覚情報処理としては, 初めは人間を観察す るときと同等の処理が行われ，次に，人間とは異なる処 理が行われる .この，先の処理と後の処理の情報処理の 齟䶣が不気味の谷を誘発する.このような路䶣か誘発さ れる仕組みを，次章で, 脳科学的知見から考察しモデル を構築する。

\section{3. 否定的反応形成過程モデルの提案}

本章では, 前章の二段階の知覚情報処理過程がどのよ うなメカニズムによって生じているかを，脳科学的知見 を踏まえて述べる．关の後， Moore のモデルを脳機能の 観点から再考察し, このメカニズムモデルと統合するこ とで, 自然な拡張を目指す。

\section{$3 \cdot 1$ 扁桃体を中心とした感情の二重経路モデル}

扁桃体は, 大脳辺縁系に位置し, 動物が感覚受容器か ら得た外界からの刺激の本能的な価值 (以下, 情動価値) を決定づける重要な部位であり，情動反応を形成する際 の中核を担っている . 扁桃体では視覚から得られた情報 が本能的に価值がある (快) か価值がない (不快) かを判 断していると考えられており [小野 12]，防衛本能システ ムを考える上では重要な働きをする部位であると言える

前章の実験結果を踏まえて脳機能に着目した不気味さ 誘因のモデルとして感情の二重経路に着目したモデルを 考える．感情の二重経路とは，対象に対する情動評価を 行う機能を有する扁桃体を中心とした情動情報処理経路 であり，情動反応は大脳皮質を経由せず迅速で杂隹多な処 理を行う経路と，これにやや遅れる形で大脳皮質を経由 して詳細な処理を行う経路の二つの経路から形成されて いる [LeDoux 96] . この前者の情報処理経路を低位経路， 後者の情報処理経路を高位経路と呼ぶ .これらの経路に より, 不気味の谷は低位経路において人間に酷似したエー ジェントを人間であると評価し，高位経路において非人 間であると評価する．この評価間の齟䶣を起点として不 気味さが生起すると考えられる．この感情の二重経路を 用いた不気味さ生起の説明モデルは，Shimada らによっ ても同樣のモデルが提案されている [Shimada 07] .

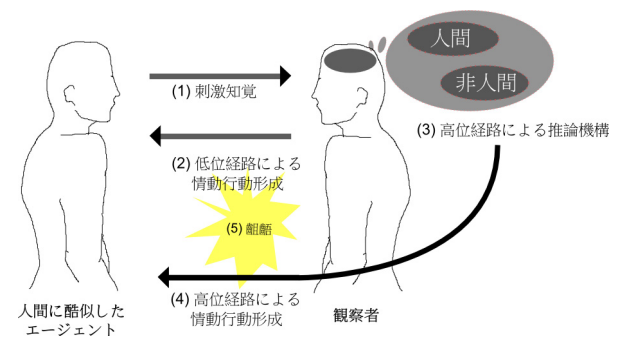

図 6 本研究で提案する否定的情動反応形成モデル

\section{$3 \cdot 2$ 先行研究とのモデル統合}

本節では，Moore モデルを脳機能モデルとして再解釈 することで, 前節の感情の二重経路のモデルとの統合を 行い, より汎用性の高いモデルとして提案する .

まず，Moore のモデルの背景にある知覚のマグネット 効果に関しては，視床・大脳皮質の機能に着目した自己 組織化マップを用いたモデルがある [Guenther 02] .この モデルに対して， Moore が参考にした Feldman のモデ ルはベイズ推定によるモデルであり，こちらも知覚のマ グネット効果を説明している．ところで，このベイズ推 定と大脳皮質の間には関連性が示唆されており，従って， ベイズ推定から構築した Feldman のモデルおよび Moore のモデルは大脳皮質の機能と密接に関係していると考え られる.また , ベイズ推定において与えられる確率すな わち, 事前確率は, 海馬に貯蔵された記憶情報が参照さ れる確率に相当すると考えることができる．

以上から, 脳機能の観点から構築した, 本研究で提案 する否定的情動反応のモデルを図 6 に示す . 人間に酷似 したェージェントを観察した際，人間は低位経路による 情報処理により，人間を観察した場合と同等の情動反応 が起こる.この時，対象に対して注意が喚起され視線が 向けられる．これに対して，高位経路による情報処理で は，対象が人間ではないという情報が処理される．以上 の二つの経路の䶙橂がさらに知覚されることで, エージェ ントに対して否定的な反応が形成され，視線がより集中 的に向けられると考えられる。

\section{$3 \cdot 3$ 視線制御と 報酬系}

前章の視線計測実験において，人間の顔画像観測時と CG 描写された人間の顔画像観測時では，光れ攵れの目 に対する視線停留時間に特徵的な差が見られた .この点 に関して，本モデルを拡張することで説明を与える。

まず，本実験において被験者は提示された刺激が人間 か非人間かを判断する課題を課せられており，この課題 は，初めに形成された人間/非人間の期待に沿う情報が 知覚され，判断の確信度か増加することで回答ができる， と考えることができる．すなわち，人間に類似度が高い エージェントに対しては, 本課題は低位経路で形成され た期待されるカテゴリー (人間) に対して，光れに沿う 情報がいかに高位経路によって知覚されるかという枠組 
みで捉えることができると考えられる . 各経路における 反応は情動行動として表出され，対象の目に視線を向け るという行動の促進あるいは抑制に寄与していると考え ることができる．以上のような視線注視行動に関しては， 強化学習の枠組みで考えると説明が可能である.強化学 習の機能的体系は，報酬系に大きくかかわる脳部位であ る線条体 [Wichmann 14]を考えることで説明できる.こ の線条体は，扁桃体を含む大脳辺縁系からの投射 (p.971) と，大脳皮質からの投射(p.963)を受けていることが知ら れている [Wichmann 14]．乥こで，対象を知覚する際に 辺縁系により得られる情動評価と，大脳から得られる期 待値を兰れ光れ受け取り，強化学習の枠組みとして，両 者の差分だけ視線を向けるかどうかの情動行動か制御さ れると考えられる .

次章以降で, 本章で提案したモデルをシミュレータ上 に実装し，シミュレーションを行った結果について述べ る.尚，シミュレーションは以下の二部から成り立って

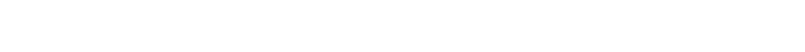
されている.一点目は, 各脳部位がどのように接続して いるか, 次に, 弚れらの脳部位が活動した時に各脳機能 がどのように作用するか，という観点からシミュレータ 上に本モデルを実装した . 二点目は，本モデルを脳部位 の接続関係を陽的に記述せず，各脳部位の機能面に着目 して実装した 。

\section{4. モデルの定性的記述}

本章では, 前章で提案したモデルに関する各脳部位の 物理的/機能的結合を定性的に記述する. 次に, 刺激が 入力された際に対象に対する情動評価が時系列的にどの ように変化するかに関してシミュレーションを行った結 果に関して述べる。

\section{$4 \cdot 1$ モデルにおける脳部位の物理的／機能的結合構造}

本モデルで取り上げた脳部位は, 視床, 扁桃体, 大脳 皮質，海馬，線条体である。弚こでまず，これらの脳部位 の各機能を脳科学的知見を基に抽出し，乥れらの神経生 理学的結合関係から機能の結合を試みる.次に , シミュ レータを用いてこの機能的結合関係を定性的に記述する． 最後に , シミュレータ上で構築されたモデルに対して入 力情報を与え，得られた出力から不気味さがどのように 表現されるかを考える．ただし，シミュレーションにお ける重要な点として, 本研究では光の具体的な定量値に 着目せず，境界標 ( 0 や閾値) との大小関係のみを扱う .

視床は感覚器官から得られた情報の中継地点であり, 得 られた情報を扁桃体および感覚皮質へと伝達する [LeDoux 96] . 次に , 扁桃体は得られた刺激の情動評価を行い, 刺 激が個体にとって価值があるか (快) 価値がないか (不 快）を判断する [小野 12] .さらに, 扁桃体は, 顔, 特に 表情に反応すること [小野 12], また同じ顔の繰り返し
呈示によって炎の活動度が抑制されること [西条 05]が 知られている . また, 線条体を含めた大脳基底核は強化 学習との関連性か指摘されている [Wichmann 14] ことか ら，期待報酬量と報酬の差分だけ行動を強化するものと 考えた。

次にこれらの機能を定性的に記述・定式化する .これ にあたっていくつかの仮定をおいた . まず扁桃体は, 知 覚した情報の情動評価値 $v(t) \in \mathbb{Q}(\mathbb{Q}$ は定性値を表す) を決定し，关の定性的な值に沿って情動行動を起こさせ ると仮定した（実際の行動は視床下部に伝達されること で生起する) .また，大脳皮質は対象に対する期待值 (報 酬予測) $\kappa \in \mathbb{Q}$ を計算し，海馬は扁桃体の情動評価から 計算される対象の評価値 $V$ (三情動評価値の和算) を大 脳皮質が算出した期待値へと収束させるように情動評価 を行うように働くと仮定した .すなわち，これは対象に 対する評価値 $V$ か時間 $t$ に対して, 以下の力学系に従う ことを表す．

$\frac{d V}{d t}=(\kappa-V) V$

最後に，大脳基底核における線条体を「辺縁系から得られ る評価値と大脳皮質て計算された期待値との差分の大き さに比例して, 情動行動を強化する系」と仮定し， $\kappa-V$ を計算し，この值が大きいほど，対象の目を見るという 情動行動か起こりやすいということを表現した . また, 対 象の目を見るとき，観察者は視覚的に情報の入力を受け ているので, このとき視床 (情報の入力部) の活動度が 高まることを仮定した .

以上の機能は各脳部位の活動度が 0 以上の場合におい て機能するようにした .この活動度は各脳部位に関して 定義され，これが閾值を超えると結合された脳部位の活 動度が上昇することとした．つまり， $n$ を本研究で用い る脳部位の数として $, i, j \in\{1, \cdots, n\}$ に対して，ある脳 部位 $X_{i}$ における活動度を $a\left(X_{i}\right), \omega_{i j}(i \neq j)$ を脳部位 $X_{i}, X_{j}$ の接続強度,$\theta_{i}$ を $X_{i}$ の活動閾值として,

$$
\begin{aligned}
\frac{d}{d t} a\left(X_{j}\right)= & \sum_{i \in\{1, \cdots, n\}} \omega_{i j} \operatorname{sign}\left(a\left(X_{i}\right)-\theta_{i}\right) \\
& -\sum_{k \in\{1, \cdots, n\}} \omega_{j k} \operatorname{sign}\left(a\left(X_{j}\right)-\theta_{j}\right)
\end{aligned}
$$

とする . 今回は , $\omega_{i j}=0.3, \theta_{i}=0.5$ で固定した . また， 初期の情動評価値を $V(0)=1$, 期待評価値を $\kappa=10$ で 与えた . 尚, これらパラメータは著者らか数度の試行の うちから一つを選択したもので, この数值以外にも最適 なパラメータが存在する可能性がある .このときの, 選 択の基準としては, 人間の目を観察している際の扁桃体 が活動後減少しているか，を中心に行った．

本モデルを記述するにあたり，シミュレータ STELLA*2を 用いた .このシミュレータでは, stock と呼ばれる変数に

\footnotetext{
$* 2$ isee systems: STELLA ${ }^{\circledR}$, Systems Thinking for Education and Research http://www.iseesystems.com/softwares/ Education/Stellasoftware.aspx
} 
対して, inflows (単位時間の入力量) と outflows (単位 時間の出力量) を定義することで， stock の值の時系列 的変化 (微分方程式) を得ることができる．また，この stock 間を flow で結合することによって, 変数と変数の 関係性を記述し，系のダイナミックスか記述可能となる .

図 7 に視床と大脳皮質の接続をSTELLA に実装した樣 子を表す . 各四角は視床と大脳皮質の活動度を表す . 視 床の活動度が視床の情報伝達の閾值を超えると，伝達の on/off が切り替わり，二つの四角を結ぶ flow によって， 活動度が伝搬する．すなわち，視床の活動度が下がり， 大脳皮質の活動度を上昇させるということを模式化して いる .

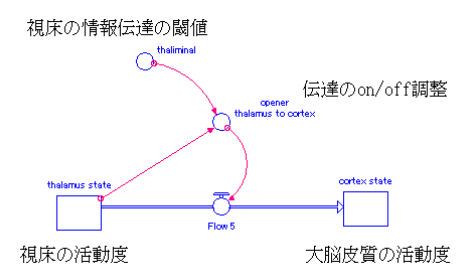

図 7 視床 (Thalamus) と大脳皮質 (Cortex) との接続を表した模式図

構築したモデル全体の概要を图 8 に示す . 大きく Evaluation とした評価機能の機構と, 光れ以外の Connection とした各脳部位の接続記述からなるモデルである . また ， 入力としてェージェントの目の形態的特徵 (強膜の広さ [Kobayashi 01] と目の大きさ [Seyama 07]) の人間の目に 対する類似度を用いた.これらは 0 から 1 の值を取り，こ れらの積が 0.5 を超えると情動評価がポジティブに，0.5 を下回ると情動評価がネガティブに働くように設定した .

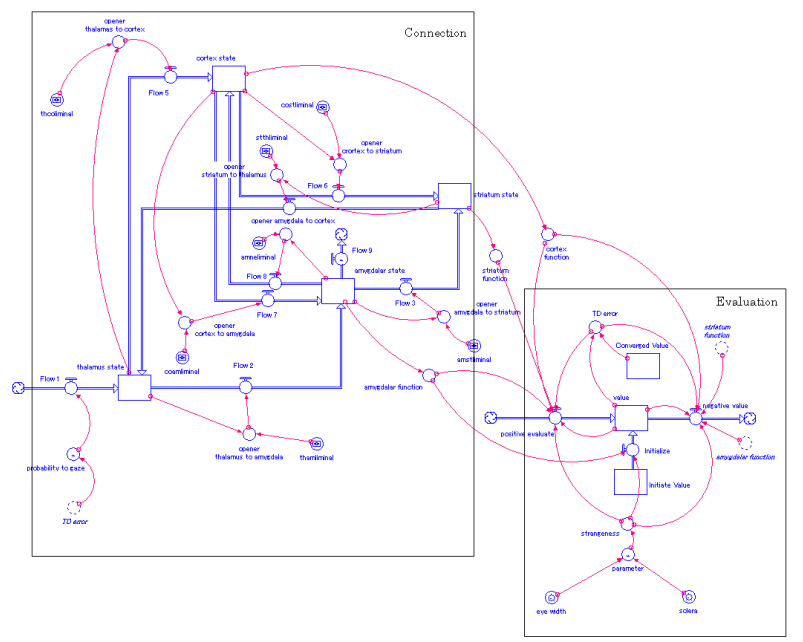

図 8 STELLA において構築した本研究のモデル

\section{$4 \cdot 2$ 対象に対する評価值の時系列的変化}

エージェントに対する評価值, エージェントの目に視 線を向ける程度，および各脳部位の活動度に関して定性
的関係に着目して記述を行い，シミュレータ上にモデル の実装を行った . 本研究では各变数の定性的関係に着目 しているため, シミュレーション上定量的な値を用いて いるが, 弚れらの具体的数值には意味を持たないことに 留意されたい，したがって, 以後, 各変数の時系列的な 増加および咸少のみに着目する . 次に , 入力 (強膜の広 さと目の大きさ) に対する情動状態 (ポジティブな評価 あるいはネガティブな評価の二値) を評価し，時間経過 によって観察対象に対する評価值が時系列的にどのよう に変化するかを, シミュレーションを行うことで分析し た .シミュレータにおいて入力情報を与えた際に，評価 值 $V$ と対象を見るかどうかを選択する確率 $\kappa-V$ の時 系列的変化か泪 9 (左) として, 扁桃体の活動度の時系列 的変化が図 9 (右) として得られた . 図 9 の上段は強膜 の広さと目の大きさの積が 0.5 を上回る場合，すなわち， 人間の目と構造的にかなり近いと考えられる場合，下段 は積が 0.5 を下回り，人間の目と構造的に異なっている

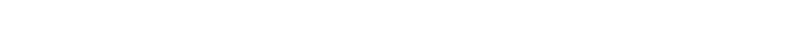
時と非人間観察時に対応し，グラフは光れぞれ被験者の 評価值, 対象の目を見る割合，および扁桃体の活動度の 時系列的変化を表現している.

評価および脳部位の活動に関して述べる．まず，人間 の目を見ている場合であれば，ある時刻以降は一定の評 価値 (期待評価値) に収束および扁桃体の活動も非活動 状態 (活動度 $=0$ ) となることが示唆された .一方で, 人 間の目と異なる構造のものを見ている場合は, 評価値は 0 へと収束し , 扁桃体の活動状態も不安定になる (活動度 が振動する) ことが示唆された .グラフの結果から，人間 の目を観察している際は, 扁桃体はある時刻まで活動が 続けられるが一定時刻を過ぎると，非活動状態となるこ とが示された .これに対して，人間の目と異なる構造を 持つエージェントを観察している場合は, 時間が経過し ても扁桃体の活動状態は持続していることが示唆された .

\section{$4 \cdot 3$ 考察と課 題}

$4 \cdot 2$ 節で示したシミュレーションの結果から，人間を 観察しているときは, 対象に対する評価値が徐々に高く なっていくことが示唆された . 視線を向けるかどうかに 関しては, 線条体の強化学習の仮定から, 期待値と評価 值の差分が小さくなるに従い，乥の確率は減少する．実 際, 図 9 (左上) において, 評価値 (1:value) が増加し, 一定値 10 (期待值) に収束しており，他方視線を向ける 確率 (2:probability to gaze) が減少している. 図 9 (左上) は入力として人間の目の形態に近いものを与えた場合で あり，人間を観察している場合に該当する．一方で，人間 図 9 (右上) は入力として人間の目の形態と異なるものを 与えた場合であり，非人間を観察している場合に該当す る.このとき，視線を向ける確率 (2:probability to gaze) は常に高い值を取っており，人間を観察している場合と 比較して, 対象に対する視線停留時間が長くなることを 

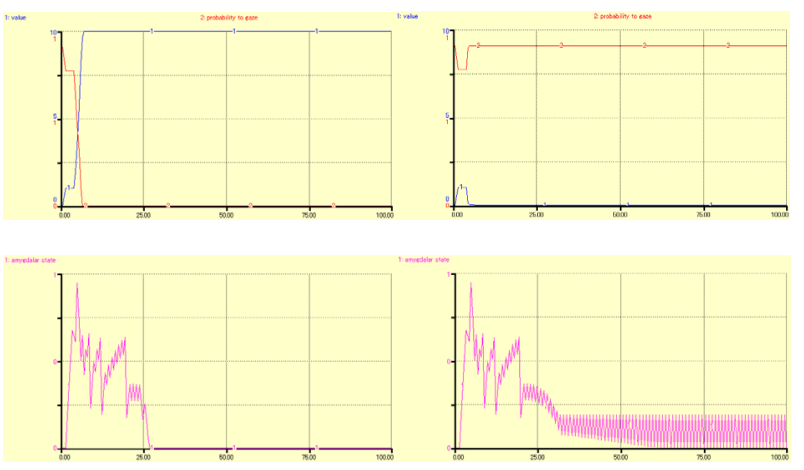

図 9 (上図) 人間の目 (左) および人間の目と異なる構造のものを観測中の評価と対象を見るという行為の選択確率の時系列的変化 (下図) 人間の目 (左) および人間の目と異なる構造のものを観測中の扁桃体の活動度の時系列的変化

表している .このとき , 図 9 (右下) から扁桃体の活動 度を確認すると，持続的に高い值をとっていることが分 かる.これは, 視線を向ける確率が高いため, 入力を受 け付ける視床の活動度が高まるためである . Minato ら は, アンドロイドと会話を行う場合は, 他者と会話して いる場合に比べ，相手の目に対する視線停留頻度が多い ことを実験的に明らかにし，これは人間がアンドロイド との相互理解を試みようとしたと考察している [Minato 04] .一般的に人間は他者とコミュニケーションを取る上 で，他者の目から樣々な情報を読み取ることが知られて いる．従って，積極的に他者を知ろうと試みがある場合 は他者の目に対する視線停留時間か増加し，樣々な情報 が処理されると考えられる．以上から，視線計測実験に おいて，CG 画像 2 の目に対する視線停留時間が，人間 の目に対する視線停留時間よりも長くなったこともこの シミュレーションの結果からも説明される .

ここで実装されたモデルでは, 入力の初期値によって 正の情動評価になるか負の情動評価になるかが決定的で あるという課題があった .つまり，入力の目の形態的異 常度が 0.5 以上で与えられれば正の情動評価，0.5 以下 で与えられれば負の情動評価となる .この入力は光の後 の系の挙動すべてに影響を与えることから，この箇所を 適切な表現に改める必要がある . また, 実際の実験では, 目以外にも鼻や口などに視線が移ることが考えられるた め, 弚れらの視線移動を考慮に入れた実装を行う必要が ある. 乥こで, 次章ではこの点を解消したモデルの再実 装を行い, シミュレーションの結果に関して述べる。

\section{5. エージェントに対する視線移動を考慮した モデルの再実装}

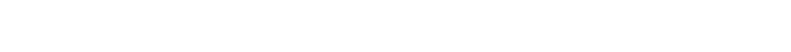
に異常度を設けて，どの部分に対して情動評価を行うか， という観点を導入することでモデルを再構築した .これ によって時系列て評価の正負が異なるようにした .本章で は, 異常度と各脳部位の機能的特徵に関する仮説を述べ, どのようにモデルを再実装したかに関して各パラメータ
の定性的関係を述べる．

\section{$5 \cdot 1$ 着目点における異常度と視線}

着目点とは, 先に述べた刺激の顔部位を表し, 強膜の 広さ $E y 1$, 目の大きさ $E y 2$, 鼻の大きさ Nos, 口の大き さMou からなる.ここで, これら着目点の特徽量集合 を $\Lambda=\{E y 1, E y 2, N o s, M o u\}$ として与える . また ，人 間に酷似したエージェントの各着目点 $\lambda \in \Lambda$ に対して異 常度 $\operatorname{abn}(\lambda)$ を定義する . 具体的には, 強膜の広さに関 する異常度 ey1, 目の大きさに関する異常度 ey 2 , 鼻の 大きさに関する異常度 nos, 口の大きさに関する異常度 mou を定数として設定した.これらは, 弚れ攵れ 0 以上

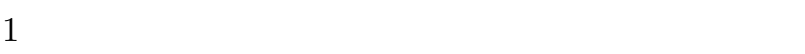
広さ, 目の大きさ, 鼻の大きさ, 口の大きさ) を見る確 率 $P_{\text {gaze }}(X=\lambda)$ は, 弚れ光れの異常度を各異常度の合 計で割った値として以下で定義した。

$P_{\text {gaze }}(X=\lambda) \equiv \frac{\operatorname{abn}(\lambda)}{\sum_{k \in \Lambda} \operatorname{abn}(k)}$

この確率が最も高い着目点 $\lambda$ に対して人は視線を向けて異 常度を知覚すると考えた . また , この確率 $P_{\text {gaze }}(X=\lambda)$ は, 以下の更新式に従って順次変更される.ただし,$c$ は 視線遷移のしやすさを表すパラメータである .

$$
\begin{aligned}
& \Delta P_{\text {gaze }}(X=\lambda) \\
& = \begin{cases}-c & \text { 視線が向けられていた場合 } \\
c / 3 & \text { otherwise }\end{cases}
\end{aligned}
$$

この更新式は，視線が向けられていた着目点が一定の割 合 $c$ で視線を向けなくなることを表している．弚の他 (otherwise) を $c / 3$ だけ増加させているのは, $P_{\text {gaze }}(X=$ 入) か確率であり，これらの合計が 1 になる必要があるた めである . $c$ が大きければ大きいほど, 他の着目点に視 線を向けやすいという性質を表している．

\section{$5 \cdot 2$ 各パラメータの関係}

本モデルのシミュレーションを行うにあたって，実装 面では図 10 のような情報の流れを想定した. $\mathrm{M}^{+}$は変 
数間の単調増加関係を, $\mathrm{M}^{-}$は変数間の単調減少関係を 表している．また， $f_{1}, f_{2}, f_{3}$ は一方の值が定まると，あ る規則に従い矢印の先の変数が定まることを示している． 各詳細に関して以下に述べる。

まず $f_{1}$ に関しては, 時刻 $t$ において各着目点を見る確 率が最大の入を抽出し, 弚の部位に対して定義された異 常度を時刻 $t$ の異常度 $\operatorname{abn}(t)$ とする関数である.すなわ ち, $\operatorname{abn}(t)$ は，兴の時刻において視線を向けられる確率 が最大である着目点 $\hat{\lambda}=\arg _{\lambda} \max \left(P_{\text {gaze }}(X=\lambda)(t)\right)$ に 予め定義された異常度 $\operatorname{abn}(\hat{\lambda})$ で与えられる . 次に , 扁 桃体の抑制に関わる機能 $f_{2}$ に関して述べる.一般的に扁 桃体の応答は情動価值である報酬・嫌悪の程度に応じて 強くなると考えられている [小野 12](p. 111) ため, 本研 究では, エージェントの顔の特徵部位から異常度が高い 部分を検知し，異常度に比例して扁桃体が活動すると仮 定した . 扁桃体は繰り返しの顔提示に対して活動が低下 することが示唆されている [西条 05] . また, 一方で, 扁 桃体と海馬は協調して記憶形成に関わっていることが知 られている [小野 12] ことから，扁桃体で形成された情 動評価値は，弚の正負の情報が海馬へと伝達・蓄積され ていくと仮定した .この仮定から，海馬に一時的に保持 された扁桃体の情動評価に関する時系列的な情報に対し て, 各単位時刻の評価の定性值が直前の評価と同じであ れば扁桃体の活動を抑制させるという機能によって実現 されていると仮定した . 乥こで, 各時刻の評価が直前の 評価と同じであれば「カウンター」と呼ばれる変数に 1 を加え，乥れが直前の評価と異なればカウンターを 0 に 戻す機能を $f_{2}$ として与えた . また , カウンターの初期値 は 0 とした .

最後に $f_{3}$ に関しては, 予め定数として与えられる, 見 ている着目点の変更率を用いて, 各着目点を見る確率を 式 (4)に則り変更させることを表す .

以上から，本シミュレーションの全体の流れを以下に 示す. .ージェントの顔の特徵部位から異常度が高い部 分を検知し，異常度に比例して扁桃体が活動する．ただ し，この扁桃体の活動は感情の二重経路による二つの処 理に分けられ，時間的に早い段階における杂隹多な情報処 理による活動と，これにやや遅れる詳細な情報処理によ る活動に分けられる.ここで, 早い段階の処理において は，ある一定值に満たない異常度は 0 として扱われる． この一定値は感情の二重経路における低位経路の情報処 理に関する雑多さを表している.

次に, 扁桃体の活動が上昇すると, 異常度 abn. に反比 例して，刺激に対する情動評価値が与えられる．従って， この評価值 $V$ は以下の式に従う .

$V(t)=-$ abn. $+(1-$ abn. $)$

ここで, $1-$ abn. は正常度を表し，これと異常度との大 小で, 情動評価の符号が決まるように設定した . また , こ の情動評価が和算されていくことで刺激に対する評価が
決定される．また，一方で，情動評価値は，弚の正負の 情報が海馬へと蓄積されていく.この符号が連続して同 じである時，カウンターが増加する .このカウンターが 増加するということは, 扁桃体が刺激に対して連続して 定性的に等しい評価を実行していると考えることができ る.このカウンターの増加に伴って扁桃体の活動を抑え る抑制度が上昇され，扁桃体の活動が減少する．しかし， 本研究では, 海馬が直接扁桃体を抑制しているとは考え ず，この扁桃体を抑制する仕組みとして，前頭前野の機 能に着目する 。

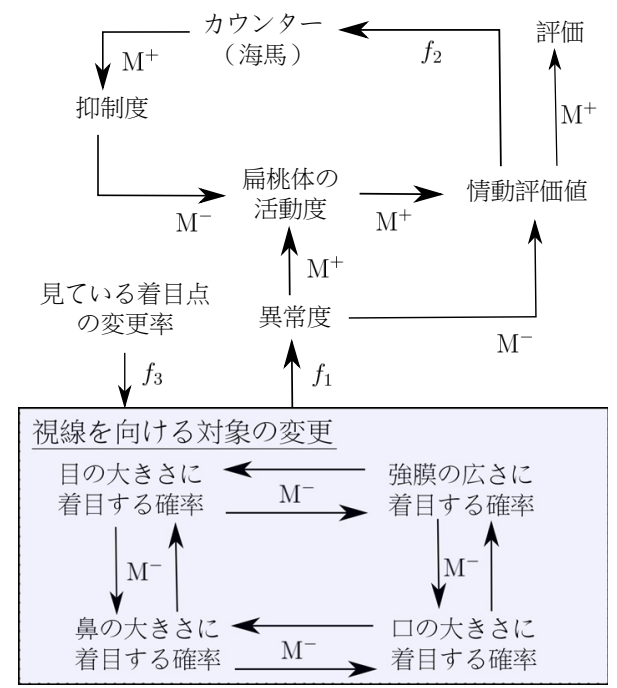

図 10 各パラメータの定性的関係

眼窩皮質の機能に関しては広く研究が進められており， その多くの機能が考察されてきた . 眼窝皮質は扁桃体や 海馬などの情動に関連する部位と相互の連絡を持つこと が知られており [Kingelbach 04]，これら機能の中でも 「扁桃体における情動および行動発現を制御している可 能性が示唆」されている [小野 05] ことは重要な知見で ある. 一方で, 背外側前頭皮質 [小野 05] や内側前頭皮 質 [LeDoux 96](pp.295-297) も扁桃体への抑制に関与し ているとされる . 従って扁桃体の活動が上昇すると抑制 度が上昇するという点に関して，この前頭前野の働きを 仮説として設けた 。

\section{$5 \cdot 3$ シミュレーション結果}

前節で述べた各変数の定性的関係を，統計処理言語お

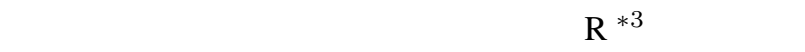
述し, 各部位に対する異常度, 低位経路における情報処 理の雑多さ, 着目点の変更率をパラメータとして変化さ せ，対象に対する評価值がどのように変化するかに関し てシミュレーションを行った .

なお，本シミュレーションでは，各部位に対する異常 度のうち, 目に対する異常度のみを考え, 弚の他の鼻の

*3 The R Project for Statistical Computing: http://www. r-project.org/index.html 
大きさに関する異常度や口の大きさに関する異常度は， 異常なしか, あるいは異常があっても極めて小さい値で あると仮定した . 乥こで, 鼻の大きさに関する異常度を 0.0 ，口の大きさに関する異常度を 0.1 として与えた . ま た，低位経路における情報処理の雑多さに関しては 0.7 を超えないものは異常なしとするものとして与えた .

時系列に関して対象に対する評価值の変化と, 扁桃体 の活動度の変化を図 11 に示す . 扁桃体の活動度が振動し ている点に関して，まず活動度の減少に関しては情動評 価の符号が一定であると，前頭前野からの抑制が起こり， 扁桃体の活動か抑えられるという点に関係があると考え られる．また，弚の次に活動度か増加している点に関し ては，再び異常度が高いところに着目点か移動すること で, 扁桃体の活動が増加したためであると考えられる .

次に, ey1 か ey 2 が 0.7 を超えていない場合は単調に 評価が増加する一方で, ey 1, ey 2 が 0.7 を超えると評価值 が全体的に減少する傾向があることが分かる．また扁桃 体の活動に関しては, ey 1 か ey 2 が 0.7 を超えていない場 合は全体として徐々に活動が減少していく傾向にあるが， ey1,ey2 のいずれか一方が 0.7 を超えると扁桃体の活動 は減少せず，活動か継続されることが示唆される．また， ey 1 ,ey2 のいずれか一方が 0.7 を超えている場合では，観 察する顔の着目点をどれくらい変更しやすいかを表す変 更率が高い場合に比へ，変更率が低いときは, 時間が経 過するに従い，エージェントに対する評価が負の方向へ と大きく変化することが示唆された .すなわち, ある着 目点を継続して見やすい場合は，エージェントに対して 否定的な反応を抱きやすくなることが示唆された .

\section{4 考 察}

$5 \cdot 3$ 節で得られた結果から，異常度の值 0.7 を境にし て評価値が全体的に増加するか減少するかが決定される． この 0.7 という值は, 低位経路における異常度の検出フィ ルタとして設定した值であるため，0.7 よりも值が高い ということは，異常が低位経路の段階で検出されるとい うことであると考えられる．つまり，低位経路における 杂隹多な情報処理において，異常であると検出される場合 は, 全体として対象に対する評価か下がる .これはモデ ルにおいて「先に人間と同等の処理を行う」という点に 関して反する条件であると言える

この原因として考えられることは, 以下の二点があげ られる，一点目は, 今回のモデルにおいて，目，鼻，口 に関する異常度をすべて等価に扱っているという点であ る. 本視線計測実験や, Minato らの研究 [Minato 04] か らも，人間はエージェントの目に対して特異的に反応す ることが分かる．これは, 人間の目に対する反応が特異 的であることを示唆しており, 鼻や口とは異なった対象 として扱う必要があると考えられる。

二点目は, 視線の変更率が一定であるという点である. これは, 着目点の変更率が小さい場合は, 異常度の大き
い箇所に常に視線を向けているということを表すため， 異常度が極めて高い箇所があると評価か下落し続けるこ とにつながる . 低位経路の働きによって人間はエージェ ントに対して人間であると期待する一方で, 高位経路に よって異常な目を検知することで, 期待と評価の間に齟

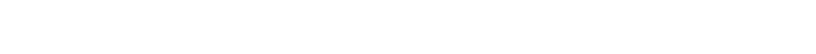
かどうかの確証を取るように，目を除く他の情報（例え ば口や鼻) に視線を向け，詳細な情報処理を行うと考え られる.このような枠組みは人間の選択的注意に関わる と考えられるため，この点を踏まえたモデル設計が必要 になると考えられる．

また，着目点のうち，いずれかの異常度が $0.7 を$ 超えた ところから，評価の值か振動するような現象が見られた 。 この振動は正の方向に評価がいくか，負の方向に評価が いくかが常に競合している状態であると考えられ，これ までのシミュレーション研究の結果では見られない .

\section{6. 総 合 考 察}

得られたモデルに対して, 辺縁系, 海馬, 大脳皮質 (前

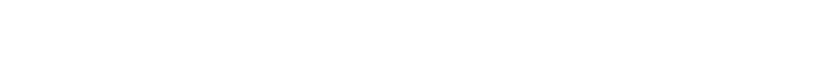
タ上で定性的に結合した . 次に, 人間の顔や人間の顔を 模して作成された顔を仮想的な入力として与え, 出力と して入力に対する評価值および扁桃体の活動度の時系列 的変化を得た .この結果, 人間の顔を見ている場合は,対 象に対する評価が持続的に増加すること，また扁桃体の 活動は見られるものの, 時間が経過するに従い減少する ことが示唆された .一般的に, 扁桃体は人の顔を見る際 に賦活すること，また繰り返し提示すると光の活動が減 少することが知られており，これは产の現象を説明して いると考えられる．また，人間ではない顔を見ている場 合は, 評価が減少傾向 (あるいは振動) にあること, ま た扁桃体の活動が時間的に持続されることが示唆された 。 このような持続的な扁桃体の活動は, 他の脳部位, 特に 皮質や側坐核へと伝達され, 全体として脳活動が持続さ せられると考えられる .

一方で, 人間の顔の形態に極めて近いエージェントを 観察している場合, 人間のエージェントに対する評価が 増加減少を繰り返す(振動する) ことが示唆された 。こ れは, 対象に対する心的評価が快・不快を繰り返してい ることを示唆しており, 人間がェージェントに対して抱 く不気味さの樣相を表していると考えられる．すなわち， 不気味さとは, 人間がエージェントに対して快状態にあ りつつも不快状態になる要素を持つ状態として位置付け ることができると考えられ，一過性の感情という枠組み で捉えるのではなく，時系列的に混雑した快/不快の評 価の不安定さとして不気味さを捉えられるべきであるこ とが示唆される．換言すれば，エージェントに対する不 気味さは単なる情報の婳䶣ではなく，快/不快の両状態 が生起している必要があることが示唆される. 

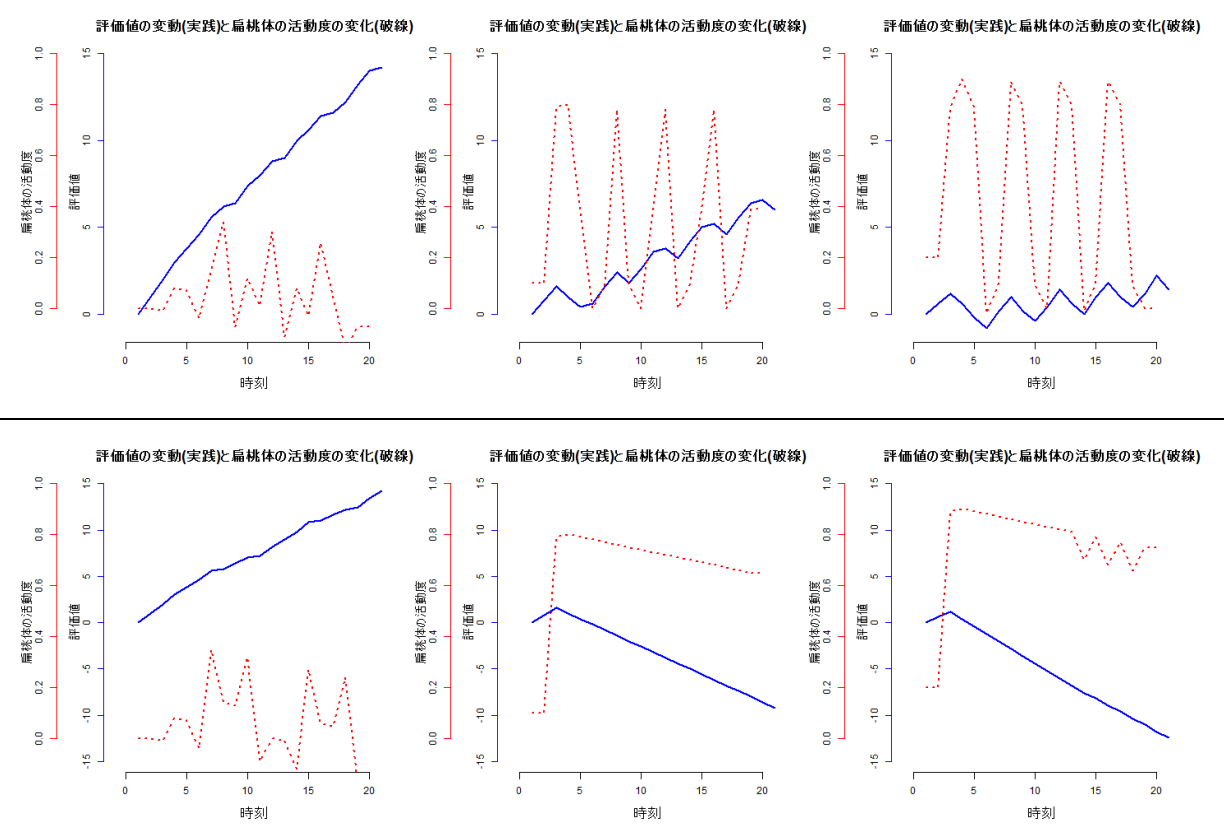

図 11 時系列に対する評価値の变動 (実線) と扁桃体の活動度の変動 (破線) (左図 : ey $1=0.2, e y 2=0.4$, 中央図 : ey $1=$ $0.8, \mathrm{ey} 2=0.4$, 右図 : ey $1=0.8, \mathrm{ey} 2=0.9$, 上段 : 着目点の変更率 $c=0.2$, 下段 : 着目点の変更率 $c=0.02)$

これまで, fMRI を用いて, 人間と非人間観察中の被験 者の脳活動がどのように異なるかを調査した研究が行わ れてきた . Saygin らは, 人間 , アンドロイド, 機械的な ロボットの关れ光れが手を振る動作を被験者に観察させ， fMRI によって被験者の脳血流量の変化を調べた [Saygin 12] .この結果 , アンドロイドが手を振っている動作を観 察した場合は, 人間や機械的なロボットが手を振っている 動作を観察した場合に比べて, 側頭葉や頭頂葉, 前頭葉 を含む広範囲の脳部位が活動していることが示唆された 。 また , 人間のような外見を持つアンドロイドは典型的な 機械の動きをしないであろうという予想に反し，実際の アンドロイドの動きは機械的である．Saygin らは，この エラーが不気味の谷と関係している可能性があると考察 している.Saygin らの研究では観察対象か動作を伴うた め, 直接本研究と照らし合わせることができないが, 不 気味の谷生起メカニズムに関する予見は本質的に本研究 のものと同じ枠組みであると考えられる .すなわち, 静 止画像であっても人間の外見のような顔が知覚されたと きは, 人間は画像に写った人型エージェントを人間であ ると予想する . しかし, 顔の細部にわたる情報を処理す ることで , 光の予想にエラーが返される .このエラーに 対する解釈の中で想起される感覚が不気味の谷であると 推察される.

以上から, 本研究で提案したモデルから不気味さとは， 人間に酷似したエージェントに対する快情動と不快情動 の混在であると予見される . 今後はこの複雑な情動状態 がどのようにして不気味さにつながるのかを検証するこ

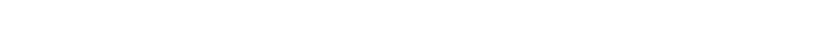
がるという点に関しては, 既往研究からは明らかになっ ておらず，本研究から得られた知見がこの関係性に示唆
を与える可能性がある .

\section{7. まとめと今後の課題·展望}

既往研究から構筑された仮説に対して, 実験を行い, 脳 機能の観点から人間に酷似したエージェントに対する否 定的な反応の生起過程をモデル化した . 具体的には, 理 論的モデルである既存モデルを，実際の脳機能の観点か ら再解釈・拡張を行った .さらにモデルをシミュレータに 実装し, シミュレーションを通して兴の挙動を考察する ことで, モデルの妥当性・検証可能性を考察した .この シミュレーションによって, 不気味さという感覚が, 快 情動と不快情動の混合状態として定義されうることが示 唆された .

今後は, 神経生理学や計算神経科学の知見をもとに本 モデルを詳細化し, 弚の妥当性の検証を行う必要がある． この点に関しては，今回のシミュレーションでは各脳部 位の結合について，常に一定の結合強度であるという課 題が挙げられる．加えて，今回作成したモデルは，紡錘 状回などの顔認知特有の情報処理機構に関してモデル化 されていない . 顔は，人間が他者を認識する上で重要な 要素であるため, 今後より詳細なモデルを構筑するにあ たり，これらの脳機能に関しても言及する必要がある．

情動反応という点においては, 人間に対する類似度が 異なるエージェントを観察している際に, 生理反応に特 徵的な差異が反映される可能性が考えられる .この生理 反応の差異を抽出し, 本モデルの妥当性を検証すること が考えられる．また，今回実験で用いた刺激は男性と女 性の画像であり，これが被験者の視線に影響を与えた可 能性が考えられる.Cheetham らは，人間，アバター（人 
間に対する類似度が低いエージェント），人間／非人間力 テゴリーの境界に位置するエージェントに対する視線の 性質に性差があるかを検証している [Cheetham 13] . 従つ て，今後は画像および被験者の性別を光ろえ，より詳細 な検証が必要であると考えられる.さらに，実際の各部 位との接続に関する問題は既往の，また今後の膨大な神 経科学の知見をもとに整合性が取れるように構築する必 要があると言える．また，本研究では不気味さは脳機能 を中心として考察したが , 不気味の谷のグラフの形状か ら, 単調増加関数と凹関数の和として考察することも可 能である . 今後は , 関数の形状の観点から不気味の谷を 説明するアプローチも検討する余地があると考えられる．

\section{$\diamond$ 参 考 文 献 $\diamond$}

[Cheetham 13] Cheetham, M., Pavlovic, I., Jordan, N., Suter, P., and Jancke, L.: Category processing and the human likeness dimension of the uncanny valley hypothesis: eye-tracking data, Frontiers in Psychology, Vol. 4, No. 108, pp. 1-12 (2013)

[Guenther 02] Guenther, F. H., Bohland, J. W., カラン 明子, Callan, D. E., 正木 信夫: 音カテゴリの学習 - ニューラルモデルと午れを 支持する実験結果-, 日本音響学会誌, Vol. 58, No. 7, pp. 441-449 (2002)

[Kingelbach 04] Kingelbach, M. L., and Rolls, E. T.: The functional neuroanatomy of the human orbitofrontal cortex: evidence from neuroimaging and neuropsychology, Progress in Neurobiology, Vol. 72, No. 5, pp. 341-372 (2004)

[Kobayashi 01] Kobayashi, H., and Kohshima, S.: Unique morphology of the human eye and its adaptive meaning: comparative studies on external morphology of the primate eye, Journal of Human Evolution, Vol. 2001, No. 40, pp. 419-435 (2001)

[LeDoux 96] LeDoux, J.: エモーショナル・ブレイン: 情動の脳 科学 (松本 元, 川村 光毅(か訳), 東京大学出版会 (2003): The Emotional Brain - The Mysterious Underpinnings of Emotional Life, Simon \& Schuster Paperbacks (1996)

[MacDorman 09] MacDorman, K. F., Green, R. D., Ho, C.C., Koch, C. T.: Too real for comfort? Uncanny responses to computer generated faces, Computers in Human Behavior, Vol. 25, No. 3, pp. 695 710 (2009)

[Minato 04] Minato, T., Shimada, M., Ishiguro, H., and Itakura, S.: Development of an Android Robot for Studying Human-Robot Interaction, Proceedings of IEA/AIE Conference 2004, pp. 424-434 (2004)

[Moore 12] Moore, R. K.: A Bayesian explanation of the 'Uncanny Valley' effect and related psychological phenomena, Scientific Reports, Vol. 864, No. 2 pp. 1-5 (2012)

[森 70] 森 政弘 : 不気味の谷, エナジー誌, Vol. 7, No. 4, pp. 33-35 (1970) http: / / ww .getrobo.com/(2013 年 2 月 16 日参照)

[西条 05] 西条 寿夫, 堀 悦郎, 田積 徹, 小野 武年: 表情認知におけ る扁桃体の神経機構, 日本薬理学杂隹誌, Vol. 125, No. 2, pp. 68-70 (2005)

[Noma 06] Noma, M., Saiwaki, N., Itakura, S., and Ishiguro, H.: Composition and Evaluation of the Humanlike Motions of an Android, Proceedings of International Conference Humanoid Robots, pp. 163-138 (2006)

[小野 05] 小野武年, 西条 寿夫: 感情と知的情報処理の仕組み, 高 次脳機能研究, Vol. 25, No. 2, pp. 116-128 (2005)

[小野 12] 小野武年: 脳科学ライブラリー3 脳と情動 -ニューロ ンから行動まで-, 朝倉書店 (2012)

[Saygin 12] Saygin, A.P., Chaminade, T., Ishiguro, H. Driver, J., and Frith, C.: The thing that should not be: predictive coding and the uncanny valley in perceiving human and humanoid robot actions, Social Cognitive and Affective Neuroscience, Vol. 7, No. 4, pp. 413-422 (2012)

[Seyama 07] Seyama, J., and Negayama, R. S.: The uncanny valley: Effect of realism on the impression of artificial human faces, Pres-
ence:Teleoperators and Virtual Environments, Vol. 16, No. 4, pp. 337-351 (2007)

[Shimada 07] Shimada, M., Minato, T., Itakura, S., and Ishiguro, H.: Uncanny Valley of Androids and its lateral inhibition hypothesis, Proceedings of IEEE International Symposium on Robot and Human Interactive Communication, pp. 374-379 (2007)

[Steckenfinger 09] Steckenfinger, S. A., Ghazanfar, A. A.: Monkey visual behavior falls into the uncanny valley, Proceedings of the National Academy of Sciences, Vol. 106, No. 43, pp. $18362-18366$ (2009)

[Thomas 14] Thomas, N. A., Wignall, S. J., Loetscher, T., and Nicholls, M. E.: Searching the Expressive Face: Evidence for Both the Right Hemisphere and Valence-Specific Hypotheses, Emotion, Vol. 14, No. 5, pp. 962-977 (2014)

[Wichmann 14] Wichmann, T., Delong, R. M.: 大脳基底核 (南部 篤 訳), In Kandel, E. R., Schwartz, J. H., Jessell, T. M., Siegelbaum, S. A., Hudspeth, A. J.(Eds.), カンデル神経科学 Principles of Neural Science Fifth Edition(日本語版第一版), 金澤一郎, 宮下保司 (日本 語版監修), メディカル・サイエンス・インターナショナル $\mathrm{pp}$. 963-978 (2014)

[Yarbus 67] Yarbus, A. L.: Eye movements during perception of complex objects, In Riggs, L. A.(Trans. Ed.),Eye Movements and Vision,(Translated by Haigb, B.), Springer US, pp. 171-211 (1967)

〔担当委員 : 片上 大輔〕

2014 年 8 月 25 日 受理

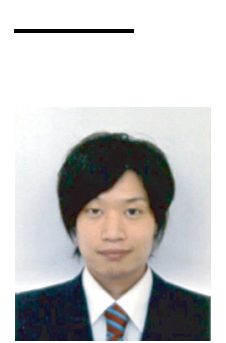

者紹介

田和辻 可昌(正会員)

2013 年早稲田大学大学院人間科学研究科修士課程修了.現 在, 同大学院人間科学研究科博士後期課程に在学中. 関心 は不気味の谷を通した人間の他者認知を実現する機構の記 述など.日本感性工学会会員.

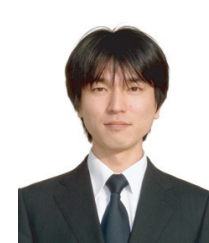

村松 慶一(正会員)

2014 年早稲田大学大学院人間科学研究科博士後期課程修 了. 博士 (人間科学) . 日本学術振興会特別研究員 DC, 早 稲田大学人間科学学術院助手を経て, 現在, 埼玉大学大学 院理工学研究科助教. 関心は印象に関する知識記述, 心の 構造の知識科学的表現など.日本感性工学会, 日本色彩学 会，教育システム情報学会，日本機械学会各会員．

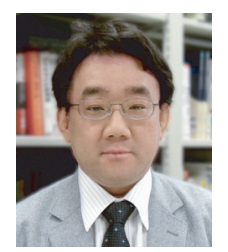

\section{松居＼cjkstart辰則(正会員)}

1994 年早稲田大学大学院理工学研究科博士後期課程修了. 博士 (理学). 早稲田大学理工学部助手, 東京学芸大学教 育学部助手, 電気通信大学大学院情報システム学研究科助 教授を経て、現在，早稲田大学人間科学学術院教授。専門 分野は, 感性情報処理, 知諳科学, 数理統計学, e-learning など. IEEE, ACM, 電子情報通信学会, 日本感性工学会, 教育システム情報学会, 日本テスト学会各会員 . 